\title{
AN EVALUATION OF THE SUITABILITY OF PRACTICES IN TEACHER TRAINING PROGRAMS FOR THE CONSTRUCTIVISM DEPENDING ON THE TEACHER TRAINEES' VIEWS
}

\author{
Aytunga OĞUZ*
}

\begin{abstract}
The aim of this study was to put forward the teacher trainees' views about how much the constructivist practices are carried out in the instructional planning, teaching-learning and evaluation processes in teacher training programs. In this survey study, a scale developed by the researcher was used. The study group was composed of 328 seniors at Anadolu University Education Faculty in 2004-2005 academic year. The analysis of the data was carried out by frequency, percent, $t$ test, variance analysis and LSD test. One third of the teacher trainees reported that the practices in planning, teaching-learning and evaluation processes of the instruction were somewhat suitable for the constructivist approach. It was found that there was a significant difference among teacher trainees' views in terms of the program they attend, but no significant difference was found in terms of gender.
\end{abstract}

Key Words: Constructivist learning environment, teacher education, teacher trainees.

\footnotetext{
* Assist. Prof. Dr., Dumlupinar University, Faculty of Education, aytunga@ dumlupinar.edu.tr
} 


\section{SUMMARY}

Background to the Study: In the constructivist learning environments, students develop their higher-order thinking skills, construct information actively and cooperate with each other. Constructivist approach in education influenced the teacher education programs deeply. Related studies focus on how the teacher traineees can acquire the teaching manners in the constructivist learning environments. It is important that instructional planning, teaching-learning and evaluations in teacher education programs are done with constructivist principles and methods. The teachers who will use the constructivist curricula should be trained based on the constructivist approach. For this reason, it must be determined to what extend the teacher traineees are trained with a constructivist approach.

Purpose and Significance: Constructivism had a great influence in teacher education programs. In the constructivist learning environments; individuals, depending on their background knowledge, construct the knowledge themselves in an active and authentic style. It is important to apply constructivist principles and methods in the teacher education programs to train teachers with a constructivist point of view.

The purpose of this study was to determine the teacher traineees' views about how much the constructivist practices are carried out in the instructional planning, practice and evaluation processes in teacher education programs. Depending on this basic purpose, the following research questions were formulated:

1. According to the teacher traineees, how much are the practices in the instructional planning, teaching-learning and evaluation processes in teacher training programs based on the constructivism?

2. Do the teacher traineees' views about whether the practices in the instructional planning, teaching-learning and evaluation processes in teacher training programs vary depending on the teaching program they attend and depending on gender?

Methods: In the study, the survey model was used. The study group was composed of 328 students at Anadolu University Education Faculty in 20042005 academic year. The data were collected on a 5-point Likert scale. The scale is composed of demographic information and three subscales. Validity and reliability of the scale was calculated. The reliability Cronbah Alpha for the subscales were $.83, .96$, and .87 , respectively. Descriptive statistical techniques, variance analysis (ANOVA) and LSD test were used for data analysis. 
Results: Depending on the research findings, teacher traineees were found to believe that instructional planning, teaching-learning and evaluation processes of teacher training programs somewhat have the constructivist characteristics. Based on the item means, there were no items that the teacher traineees totally agreed and totally disagreed. It was found that teacher traineees' views differ with regard to the teaching program they attend. However, in terms of gender, no significant difference was found among the views. As a result, depending on the teacher traineees' views, it can be said that constructivist practices do not take place very much in teacher training programs.

Suggestions: In teacher training programs, it must be given importance to the application of constructivist principles and methods. Instruction must be planned taking the teacher traineees' views, interests, wants and needs into account. In the teaching process, active learning activities and modern technology must be used. Students should take place in the evaluation process and it must be given importance to the evaluation of the learning process using various techniques. 


\title{
ÖĞRETMEN EĞİTIMİ PROGRAMLARINDAKİ UYGULAMALARIN YAPILANDIRMACI YAKLASSIMA UYGUNLUĞUNUN ÖĞRETMEN ADAYI GÖRÜŞLERIYLE DEĞERLENDİRILMESİ
}

\author{
Aytunga OĞUZ*
}

\begin{abstract}
ÖZ: $\mathrm{Bu}$ araştırmanın amacı, öğretmen eğitimi programlarında; öğretimin planlanması, uygulanması ve değerlendirilmesi süreçlerinde, yapılandırmacı yaklaşıma dayalı uygulamalara ne ölçüde yer verildiğini öğretmen adaylarının görüşlerine göre belirlemektir. Araştırmanın çalışma grubunu, 2004-2005 Eğitim öğretim yılı bahar yarıyılında Anadolu Üniversitesi Eğitim Fakültesinin son sınıflarında öğrenim gören 328 lisans öğrencisi oluşturmuştur. Tarama modelinde gerçekleştirilen araştırmada araştırmacı tarafindan geliştirilen bir ölçek kullanılmıştır. Verilerin analizi; frekans, yüzde, t testi, varyans analizi ve LSD teknikleri ile gerçekleştirilmiştir. Öğretmen adaylarının 1/3'ü öğretimin planlanması, öğretme-öğrenme ve değerlendirme süreçleriyle ilgili görüşlere kısmen katılmışlardır. Öğretmen adaylarının görüşleri arasında öğrenim gördükleri programlara göre anlamlı fark bulunmuş, cinsiyete göre anlamlı fark bulunmamıştır.
\end{abstract}

Anahtar Sözcükler: Yapılandırmacı öğrenme ortamı, öğretmen eğitimi, öğretmen adayı

\footnotetext{
* Yar. Doç. Dr., Dumlupınar Üniversitesi Eğitim Fakültesi Eğitim Bilimleri Bölümü Kütahya aytunga@dumlupinar.edu.tr
} 


\section{GİRIŞ}

Son yıllarda eğitim programlarını etkileyen önemli yaklaşımlardan biri de yapılandırmacılıktır. Yapılandırmacı yaklaşımda öğrenme; öznel, durumsal, sosyal, duygusal, gelişimsel ve sürekliliği olan bir süreçtir (Saban, 2000). Bu süreçte, bireyin sürekli keşfetmesi ve zihinsel yapılarının gelișimi söz konusudur. Öğrenen; örnekleri inceleme, öneriler getirme, fikirleri sınama, problem çözme, fikirleri; resim, grafik, haritalar vb. biçimlere dönüştürme gibi etkinliklerle öğrenmeyi etkin bir biçimde gerçekleştirmektedir (Herne, 2000). Bu anlamda yapılandırmacı yaklaşım, öğrencilerin nasıl öğrendiklerine yönelik açıklamalar getiren bir yaklaşımdır (Brooks ve Brooks, 1999). Yapılandırmacı öğrenme sürecinde öğrenenin, çeşitli etkinliklerde bulunarak kendi çabasıyla, özgün bir biçimde bilgiyi yapılandırması ve kendisini bütüncül olarak, çok yönlü geliştirmesi söz konusudur. Yapılandırmac1 eğitim anlayışı; grup etkileşimini kolaylaştırmayı; formal bilgi alanına planlı ve çoğu kez de planlamadan girmeyi, öğrencilerin var olan inanç ve anlayışlarını tanımayı ve geliştirmeyi gerektirir (Richardson, 2003). Bu açılardan, yapılandırmacı öğrenme ortamı, geleneksel öğrenme ortamından farklı özellikler taşımaktadır.

Yapılandırmacı sınıf ortamı bilgilerin aktarıldığı bir yer değil; öğrencinin öğrenmeye etkin katılımını, bilgiyi sorgulamasın1, problem çözmesini ve araştırmasını sağlayan zengin öğrenme yaşantılarının geçirildiği bir ortamdır (Demirel, 2006). Bu ortam, çok çeșitli yöntem ve tekniklerin kullanılmasına, yeni teknolojilerden yararlanılmasına ve öğrenenin, ön bilgilerini kullanarak yeni bilgileri anlamlandırmasına olanak vermektedir. Öğrencilerin ön bilgileri ve geçmiş yaşantıları farklı olduğundan, aynı yaşantıları geçirseler dahi, yeni yaşantıları anlamlandırmaları farklılık göstermektedir (Deryakulu, 2000). Bundan dolayı yapılandırmacı öğrenme sürecinde her öğrenci kendisine özgü bir biçimde bilgiyi anlamlandırmaktadır. Öğrencilerin; yapılandırmacı öğrenme ortamında, çeşitli olaylar, materyaller ve bireylerle etkileşime geçmelerinin sağlanması bireysel farklılıkları doğrultusunda, çok yönlü gelişmelerine hizmet etmektedir. Ancak, Bıkmaz'ın (2006) da belirttiği gibi öğretmenlerin, öğrencilerin bireysel farklılıklarını gözetmeleri yalnızca yöntem zenginliğine giderek değil, öğrencilerden beklentilerini de farklılaştırarak hareket etmelerini gerektirmektedir. Cook, Smagorinsky, Fry, Konopak ve Moore'a göre (2002: 403) yapılandırmacı bir eğitimci, her bireyin bir terimle ilgili anlamı kendisinin oluşturduğunu kabul etmelidir. Kısacası, öğretmenlerin yapılandırmacı öğrenme ortamlarında, geleneksel rollerini bir kenara bırakmaları, etkinlikleri öğrencilere göre düzenlemeleri ve öğrencilerin hepsinden aynı davranışı aynı düzeyde beklememeleri gerekmektedir. Yapılandırmacı yaklaşıma dayalı eğitim programlarında, hem öğretmen hem de öğrenci, geleneksel öğrenme ortamındakinden farklı roller üstenmektedir. 
Yapılandırmacı eğitim programlarının merkezinde öğrenenin olması, öğrenme hedeflerinin sürece dayalı ve üst düzey öğrenmeye yönelik belirlenmesi, öğrenme içeriğinin öğrencilerin ilgilerine dayalı ve gerçek yaşamla bağlantılı olmas1, öğrenme-öğretme ve değerlendirme etkinliklerinin öğrenenlerle birlikte planlanıp uygulanması ve değerlendirilmesi gerekmektedir (Koç ve Demirel, 2006). Yapılandırmacı yaklaşımı kullanan öğretmen, öğrenci merkezli etkinliklere yer vermeli (Pierce ve Kalkman, 2003); yapılandırmacı öğrenme yaklaşımının ilkelerini dikkate almalı ve böylece, öğrencinin, öğrenmesine ve kendi öğrenme sorumluluğunu almasına rehberlik etmelidir (Brooks ve Brooks, 1999; Olsen, 1999; Plourde ve Alawiye, 2003; Yager, 1991). Öğretmen ve öğrenciler, yapılandırmacı öğrenme ortamını birlikte planlamak, gerçekleştirmek, değerlendirmek ve gerektiğinde değişiklikler yapmak için sürekli etkileşim içinde olmak durumundadırlar.

Yapılandırmacı öğrenme planlarında; öğrencilerin, temel kavramlara ilgilerinin çekildiği; ön bilgilerinin açığa çıkartıldığı; problem durumu ile karşı karşıya getirildiği ve işbirliği içinde çözümler üretmelerinin, tartışmalarının, bilgi kaynaklarına ulaşmalarının sağlandı̆̆ı; bilgi, duygu ve düşünce paylaşımlarına ve kendilerini değerlendirmelerine olanak verildiği görülmektedir (Arslan, 2007; Bevevino, Dengel ve Adams, 1999; Gagnon ve Collay, 2001; Koç ve Demirel, 2006; Yurdakul, 2005). Böyle bir planlamanın öğrencilerle birlikte, esnek bir biçimde düzenlenmesi gerekmektedir. Başka bir deyişle, öğretimi planlamak yerine, öğrencileri için öğrenme etkinliklerini organize etmelidir (Gürol, 2002). Bu süreçte öğretmen, neleri öğreteceğini değil, öğrencilerin nasıl öğrenebileceklerini ön planda tutmalıdır. Öğrencilerin bilgiyi yapılandırmalarına ve kendilerini değerlendirmelerine olanak verecek bireysel ya da grup etkinlikleri; özgün, gerçek yaşam problemleriyle iç içe ve birincil kaynaklardan yararlanılacak şekilde ögrencilerle birlikte tasarlanmalıdır.

$\mathrm{Bu}$ etkinlikler esnasında, öğrenmenin değerlendirilmesine yönelik etkinliklere de yer verilmesi gerekmektedir. Çünkü yapılandırmacı yaklaşımda öğrenme ve değerlendirme süreci ayrı ayrı değil, birlikte gerçekleşen süreçlerdir (Deryakulu, 2000). Yapılandırmacı yaklaşımda yalnız ürün değil, süreç de önem taşımaktadır. Öğretmen ve öğrencilerin birlikte belirledikleri ölçütlere göre; grup çalışmaları, öğrenci ürünleri ve performanslar dönem süresince değerlendirilir (Özden, 2003). Bu süreçte öğrencinin, çeşitli tekniklerle (günlükler, gelişim dosyaları vb.) çok boyutlu olarak değerlendirilmesi söz konusudur (Brown ve Adams, 2001; Sönmez, 2004). Öğrenci, yapılandırmacı öğrenme ortamında kendi öğrenmesini ve arkadaşlarının öğrenmelerini değerlendirebilmeli; duygu ve düşüncelerini rahatlıkla yansıtabilmelidir. Kısacası, yapılandırmacı yaklaşım, geleneksel yaklaşımdaki gibi yalnız öğretmenin değil, öğrencinin de öğretim sürecinin her aşamasında söz sahibi olmasını gerektirmektedir. 
Öğretmen ve öğrencinin yapılandırmacı öğrenme ortamındaki bu rolleri öğretmen eğitimi programlarını da etkilemiştir. Bilgi aktarmaya dayalı yaklaşımdan yapılandırmacı yaklaşıma dayalı yeni paradigma, öğretmen eğitimi ve öğretmenin öğrenmesine ilişkin reform arayıșlarını beraberinde getirmiştir (Cochran-Simith, 2001). Bütünleşik ve sarmal yaklaşımdan yoksun öğretmen eğitimi modellerinin yetersizlikleri görülerek yapılandırmacı öğretmenlik becerilerini kazandırabilecek yaklaşımlara yer verilmesi vurgulanmaktadır (Hassard, 1999). Bu doğrultuda, yapılandırmacı öğretmen eğitimcisinden de yapılandırmacı roller beklenmektedir. Yapılandırmacı öğretmen eğitimcisi; işbirliğini, yansıtıcılığı, katılımcılığ1 ve disiplinler arası hareket etmeyi gerektiren rolleri üstlenmeli ve böylece, demokratik uygulamalara olanak vermelidir (Rainer ve Guyton, 1999). Öğretmenin; uzman olarak değil, öğrenmeyi kolaylaştıran (KinnucanWelsch ve Jenlink, 1998), öğrenmeye yardım eden (Oldfather, Bonds ve Bray, 1994) ve destekleyen rolü ön plana çıktığından; öğretmen eğitiminde öğrencilerin, etkin öğrenmenin önemini daha fazla kavramalarına ve uygulayabilmelerine olanak verilmesi gerekmektedir (Niemi, 2002).

Geleneksel öğrenme ortamlarında yetiştirilen öğretmen adaylarının yapılandırmacı öğretmenlik rollerini yerine getirmeleri çok güçtür. Öğretmen adaylarının üst düzey düşünme becerilerini geliştirmeleri; yalnız bilişsel değil, duyuşsal ve sosyal yönlerden de gelişebilmeleri, yapılandırmacı öğrenme ortamlarında öğrenmeye etkin katılımlarıyla olanaklıdır. Öğretmenin, bir dersi planlamak ve hazırlamak için üst düzey düşünme becerilerini kullanması; disiplinler arası program, işbirliğine dayalı öğrenme, buluş yoluyla öğrenme ve özgün (otantik) değerlendirme bilgisini içeren çeşitli öğretim stratejileri geliştirmesi gerekir (Casas, 2004). Bu nedenle, öğretmen eğitimi programlarında öğrencilerin; problem çözme ve kritik düşünme becerilerini geliştirmeleri; bilgi, beceri ve tutumlarını uygulamaları, analiz etmeleri ve sentezlemeleri önem taşımaktadır (White, 1995). Öğrencilere, eleştiriye yer verilen yaşantılar ve işbirliğine dayalı öğrenme ortamları düzenlenmelidir (Berry ve Loughran, 2002). Böylece, yapılandırmacı öğrenme ortamlarında öğrencilerin, yaşam boyu öğrenenler olmaları ve potansiyellerindeki değişimler sağlanabilir (Austin, 2004).

Yapılandırmac1 öğretmen eğitiminde; öğretmenlerin öğrencilere rehberlik etmeleri ve öğretim etkinliklerinde yapılandırmacı yaklaşımları kullanmaları amaçlanmaktadır (Goubeaud ve Yan, 2004; Richardson, 2003). Bunun için, öğretmen eğitimi programlarında yapılandırmacı modeller uygulanarak öğrencilerin kendi çabalarıyla yapılandırmacılığı kavramaları ve kullanmaları sağlanabilir (Oldfather, Bonds ve Bray, 1994). Öğretmen eğitimi programlarında, öğrencilere yapılandırmacığın nasıl 
kazandırılabileceği, yapılandırmacı öğrenme ortamlarının nasıl düzenlenebileceğine ilişkin çeşitli modeller geliştirilmiş ve araştırmalar yapılmıştır (Carlson, 1999; Gagnon \& Collay, 2001; Hewett, 2003; Kinnucan-Welsch ve Jenlink, 1998; Kroll, 2004; Pankratius ve Young, 1995; Pierce ve Kalkman, 2003; Plourde ve Alawiye, 2003; So ve Watkins, 2005). Öğretmen eğitimi programlarının niteliğini artırmaya dönük araştırmaların; yapılandırmacı öğrenmeyi sağlayacak etkin öğretim etkinlikleri ve performansa dayalı ya da özgün (otantik) değerlendirmeye odaklandığı görülmektedir (Goubeaud ve Yan, 2004). Öğretmen eğitimi programlarındaki yapılandırmacı etkinlikler, öğretmen adaylarının; kavramlar, planlama, öğretim ve yansıtma ile ilgili düşüncelerini olumlu yönde etkilemektedir (So ve Watkins, 2005). Böylece öğretmen adayları, bilgileri ezberlememekte, anlamlı öğrenmeyi gerçekleştirmektedir. Öğrencilerin yapılandırmacı öğrenme ortamlarında öğrenmeyi öğrendikleri gözlenmiştir (Pankratius ve Young, 1995).

Türkiye'de de öğretmen eğitiminde yapılandırmacı öğrenme ortamlarına ilişkin araştırmalar yapılmıştır (Akar ve Yıldırım, 2004; Can, 2004; Gürol, 2002; Kesal ve Aksu, 2006; Yanpar Şahin, 2003). Bu araştırmalarda, öğretmen eğitiminde yapılandırmacı öğrenme yaşantılarının yararlarına ve öğretmen adayları üzerindeki etkilerine ilişkin bulgular elde edilmiştir. Örneğin, Akar ve Yıldırım'ın (2004) araştırmasında, yapılandırmacı öğrenme ortamlarında öğrenim gören öğretmen adaylarının; anlamlı biçimde öğrendikleri, kendilerini öğretmen olarak gördükleri, performanslarının değerlendirilmesinin öğrenmelerine önemli ölçüde katkı sağladığı belirtilmektedir. Yanpar Şahin'in (2003) araştırmasında da öğretmen adayları, uygulanan yapılandırmacı öğrenme etkinliklerini yararlı bulduklarını, ögretmen rehberliğinde daha iyi öğrendiklerini belirtmişlerdir. Yapılandırmacı öğrenme etkinliklerinin uygulandığı gruplarda öğretmen adaylarının daha başarılı oldukları ortaya konulmuştur (Gürol, 2002). Bu araştırmalar, öğretmen adaylarının çağın gereksinimleri doğrultusunda, daha nitelikli eğitim almalarında yapılandırmacı yaklaşımın önemine ve çağdaş öğretmen eğitimi programlarında yapılandırmacı ilkelere yer verilmesi gerektiğine işaret etmektedir. Yapılandırmacı yaklaşıma dayalı öğrenme ortamlarında öğretmen adayları öğrenme sorumluluğunu almakta, öğrenmeye etkin katılım göstererek yeni bilgileri ön bilgilerine dayalı yapılandırmakta, anlamlandırmakta ve gelişimlerinin farkında olmaktadırlar. Bu yararlarından dolayı, öğretmen eğitimi programlarının yapılandırmacı anlayışla geliştirilmesi gerekmektedir.

Yapılandırmacı yaklaşım birçok ülkede olduğu gibi, Türkiye'deki eğitim programlarını da etkilemiş̧tir. Türkiye'deki ilköğretim programları yapılandırmacı anlayışla yeniden geliştirilmiş ve 2005-2006 eğitim-öğretim yılından itibaren bu programlar uygulanmaya başlanmıştır (MEB, 2005). 
Bunun yanı sıra, Türkiye'de öğretmen eğitimi programları da yeniden yapılandırılmış ve böylece, daha nitelikli öğretmenler yetiştirilmesi hedeflenmiştir (YÖK, 1998; YÖK/Dünya Bankası, 1998). Bu hedeflere ulaşılıp ulaşılmadığı araştırma bulguları 1şı ğında değerlendirilmelidir. $\mathrm{Bu}$ açıdan, hizmet öncesi öğretmen eğitimi programlarında öğretmen adaylarının çağdaş yöntem ve ilkelere göre ne ölçüde yetiştirildiğinin incelenmesi gerekmektedir. Türkiye'de sınıf öğretmenliği bölümlerinin eğitim programları incelendiğinde, kurama ağırlık vererek uygulamayı göz ardı eden eğitim programlarının uygulanmakta olduğu görülmektedir (Senemoğlu, 1994). Oysa bir eğitim programının başarısı uygulayıcıların becerisine bağlıdır (Arslan, 2007). Bu nedenle, yapılandırmacı yaklaşıma dayalı eğitim programını uygulayacak öğretmenlerin yapılandırmacı anlayışla yetiştirilmesi gerekmektedir. Öğretmenlerin, programlardaki değişimi sınıflarında yansıtabilmeleri için öncelikle, değişimin kavramsal alt yapısını bilmeleri gerekmektedir (Bıkmaz, 2006). Bu çerçevede, öğretmen eğitimi programlarında öğretmen adaylarının yapılandırmacı bilgi, beceri ve tutumlar kazanmalarını sağlayacak yaşantılar geçirmeleri önem taşımaktadır. Yapılandırmacı yaklaşımla yetiştirilen öğretmen adayları yapılandırmacı yaklaşıma dayalı programları uygulamakta güçlük çekmeyecektir. Ancak, geleneksel sınıf ortamlarında eğitim alan öğretmen adayları, öğretmen olduklarında yapılandırmacı yaklaşıma dayalı öğrenme ortamlarını düzenlemede sorunlarla karşılaşabilirler.

Türkiye'deki bazı araştırma bulguları da öğretmenlerin öğretimi planlama ve uygulamada sorunlar yaşadıklarını ve bazı açılardan yetersiz olduklarını göstermektedir (Kılıç, Nalçacı ve Ercoşkun, 2004; Yıldırım, 2003). Örneğin; Gözütok, Akgün ve Karacaoğlu'nun (2005) araştırmasında, öğretmenlerin kendilerini başta ölçme ve değerlendirme olmak üzere, birçok açıdan yetersiz gördükleri ortaya konulmuştur. Gökalp'in (2004) araştırmasında da öğretmenlerin meslek bilgilerinin yetersiz olduğu, eğitim ve öğretim programlarını iyi hazırlayıp uygulayamadıkları belirtilmekte ve öğretmenlerin, alan bilgilerine ve mesleki bilgilerine yönelik yetersizliklerin giderilmesi gerektiğine işaret edilmektedir. Öğretmenlerin bu yetersizlikleri önemli ölçüde, hizmet öncesi öğretmen eğitimi programlarında gerekli davranışları kazanamamış olmalarından kaynaklanmaktadır. Öğretmenlerin, yapılandırmacı yaklaşıma dayalı öğrenme ortamlarının planlanması, gerçekleştirmesi ve değerlendirilmesi süreçleri ile ilgili yetersizlikleri giderilmeden yapılandırmacı eğitim programlarının uygulanması çok zordur.

Yapılandırmacı anlayışla hazırlanmış bir eğitim programının etkili bir biçimde uygulanabilmesi yapılandırmacı davranışlara sahip öğretmenleri gerektirmektedir. Öğretmen adayları yapılandırmacı yaklaşımla düzenlenmiş 
öğrenme ortamlarında yetiştirildiklerinde yapılandırmacı yaklaşımı benimseyebilirler ve gelecekte yapılandırmacı yaklaşıma dayalı öğrenme ortamlarını rahatça düzenleyebilirler. Bunun için, yapılandırmacılığı yalnızca bilmeleri yeterli değildir; bunu nasıl uygulayacaklarını da bilmeleri gerekmektedir (Akgün, 2005). Bu nedenle, öğretmen adaylarının yapılandırmacı yaklaşıma dayalı öğrenme ortamlarında, model davranışları görerek ve öğrenmeye etkin katılım göstererek eğitim almaları önem taşımaktadır.

Ancak, Türkiye'deki öğretmen eğitimi programlarında; öğretimin planlanması, uygulanması ve değerlendirilmesi süreçlerinde yapılandırmacı yaklaşıma dayalı uygulamalara ne ölçüde yer verildiğine ilişkin çok az araştırmaya rastlanmıştır (Kesal ve Aksu, 2006). Öğretmen adaylarının, öğrenme ortamlarında, yapılandırmacı yaklaşıma dayalı uygulamalarla yetiştirilip yetiştirilmediği bilinmemekte ve bunun ortaya konulması önem taşımaktadır. Bu konuda gerçekleştirilecek araştırmalar, programlarda var olan durumun, eksikliklerin ya da yetersizliklerin ortaya konulmasina ve programların yapılandırmacı anlayışla geliştirilmesine 1şık tutabilir. $\mathrm{Bu}$ nedenle, öğretmen eğitimi programlarında, öğretim süreçlerinin ne ölçüde yapılandırmacı özellikler taşıdığının ve böylece, öğretmen adaylarının ne ölçüde yapılandırmacı anlayışla yetiştirildiğinin ortaya konulması gerekmektedir.

Araştırmanın Amacı

$\mathrm{Bu}$ araştırmanın amacı, öğretmen eğitimi programlarında; öğretimin planlanması, uygulanması ve değerlendirilmesi süreçlerinde, yapılandırmac1 yaklaşıma dayalı uygulamalara ne ölçüde yer verildiğini öğretmen adaylarının görüşlerine göre belirlemektir. Bu amaç doğrultusunda aşağıdaki sorulara yanıt aranmıştır:

1. Öğretmen adaylarının görüşlerine göre, öğretmen eğitimi programlarında; öğretimin planlanması, öğretme-öğrenme ve değerlendirme süreçlerindeki uygulamalar ne ölçüde yapılandırmacı yaklaşıma dayalıdır?

2. Öğretmen adaylarının, öğretmen eğitimi programlarında; öğretimin planlanması, öğretme-öğrenme ve değerlendirme süreçlerindeki uygulamaların yapılandırmacı yaklaşıma dayalı gerçekleştirilip gerçekleştirilmediğine ilişkin görüşleri öğrenim gördükleri programlara ve cinsiyete göre değişmekte midir? 


\section{YÖNTEM}

Araştırmada, genel tarama modeli kullanılmıştır Tarama modeli araştırmalar, geçmişte ve halen var olan bir durumun var olduğu şekilde betimlenmeye çalışıldığı araştırmalardır (Cohen, Manion ve Morrison, 2005; Karasar, 1991). Bu araştırmada da öğretmen eğitim programlarında var olan durum araştırmanın amacı doğrultusunda betimlenmiştir.

\section{Çalışma Grubu}

Araştırmanın çalışma grubunu, 2004-2005 eğitim-öğretim yılı Bahar yarıyılında Anadolu Üniversitesi Eğitim Fakültesi'nin lisans programlarının son sınıflarında öğrenim gören 467 öğretmen adayından ulaşılabilen 328 öğretmen adayı oluşturmaktadır. Çalışma grubunun program ve cinsiyete göre dağılımı Tablo 1'de sunulmuştur.

Tablo 1. Öğretmen adaylarının öğretmenlik programları ve cinsiyete göre dağılımı

\begin{tabular}{lcccccc}
\hline \multirow{2}{*}{ Öğretmenlik Programları } & \multicolumn{2}{c}{ Kız } & \multicolumn{2}{c}{ Erkek } & \multicolumn{2}{c}{ Toplam } \\
\cline { 2 - 7 } & $\mathrm{f}$ & $\%$ & $\mathrm{f}$ & $\%$ & $\mathrm{f}$ & $\%$ \\
\hline 1.Sınıf Öğretmenliği & 67 & 70,5 & 28 & 29,5 & 95 & 29 \\
2.Sosyal Bilgiler Öğretmenliği & 9 & 60 & 6 & 40 & 15 & 4,6 \\
3.Matematik Öğretmenliği & 23 & 59 & 16 & 41 & 39 & 11,9 \\
4.Okulöncesi Öğretmenliği & 54 & 100 & - & - & 54 & 16,5 \\
5.Bilgisayar ve Öğretim Tek. Öğretmenliği & 16 & 48,5 & 17 & 51,5 & 33 & 10,1 \\
6.İngilizce Öğretmenliği & 62 & 83,8 & 12 & 16,2 & 74 & 22,6 \\
7.Fransızca Öğretmenliği & 9 & 50 & 9 & 50 & 18 & 5,5 \\
Toplam & 240 & 73,2 & 88 & 26,8 & 328 & 100 \\
\hline
\end{tabular}

\section{Veri Toplama Aracı}

Veri toplama aracı olarak araştırmacı tarafından geliştirilen, "Öğretim Süreçlerine İlişkin Öğretmen Adayı Görüşleri Ölçeği” kullanılmıştır. Ölçeğin ön uygulaması Ankara Üniversitesi Eğitim Bilimleri Fakültesi'ndeki 142 son sınıf öğrencisi üzerinde yapılmıştır. Ölçeğin geçerliği faktör analizi ile belirlenmiştir. Ölçekte yer alan üç alt ölçek birbirinden bağımsız olarak düşünüldügünnden faktör analizi alt boyutlar dikkate alınarak yapılmıştır. Öncelikle, veri setinin faktör analizi için uygun olup olmadığı, KMO ve Bartlett testleri ile incelenmiştir. KMO değerleri üç alt ölçek için sırası ile 0,$83 ; 0,92$ ve 0,88 olarak belirlenmiştir. KMO oranının 0,50 'nin üzerinde olması gerekmektedir (Kalaycı, 2005). Buna göre, veri seti faktör analizi için 
uygun bulunmuştur $(0,83 ; 0,92 ; 0,88>0,50)$. Bartlett testi sonuçları, üç alt ölçek için sırası ile 435,85; 3393,92; 617,83 olarak hesaplanmış ve bulguların anlamlı olduğu görülerek ön uygulama verileri faktör analizi için uygun bulunmuştur.

Birinci alt ölçekte (Öğretimi Planlama) 10 madde yer almıştır. Boyutun tek başına açıkladığı toplam varyans \% 41'dir ve Cronbach Alpha güvenirlik katsayısı $\alpha=0,83$ 'dür. İkinci alt ölçekte (Öğretme-Öğrenme Süreci) 39 madde yer almıştır. Bu boyutun tek başına açıkladığı toplam varyans \% 41'dir ve Cronbach Alpha katsayısı $\alpha=0,96$ bulunmuştur. Üçüncü alt ölçekte (Değerlendirme Süreci) yer alan 11. maddenin ortak varyansının (communalities) 0,18 olduğu görülmüştür. Faktör analizi sonucunda, bu maddenin faktör yük değeri 0,30 'un altında kaldığından ölçekten çıkartılmış ve bu alt ölçekte 10 madde kalmıştır. Üçüncü alt ölçeğin tek başına açıkladığı toplam varyans \% 45; Cronbach Alpha katsayısı $\alpha=0,87$ 'dir. Sonuç olarak, ölçeğin tamamı, kişisel bilgiler ve üç alt ölçek olmak üzere dört bölümden oluşmaktadır. Ölçeğin yanıt seçenekleri: 1. Hiç katılmıyorum, 2. Çok az katılıyorum, 3.Kısmen katılıyorum, 4. Büyük ölçüde katılıyorum ve 5. Tamamen katılıyorum şeklinde derecelendirilmiştir.

\section{Verilerin Toplanması ve Analizi}

Araştırmanın verileri araştırmacı tarafından toplanmıştır. Verilerin analizinde; frekans, yüzde, varyans analizi (ANOVA), t testi ve LSD testi kullanılmıştır. Elde edilen veriler, 5'den (tamamen katılıyorum) 1'e (hiç katılmıyorum) doğru puanlar verilerek kodlanmış ve bunlar toplanarak her öğretmen adayı için toplam puan elde edilmiştir. Bu puanlar görüşlerin farkını sınamada kullanılmıştır. Öğretmen adaylarının görüşleri bir tek seçenekte toplanmayıp hiç katılmıyorum ve çok az katılıyorum seçeneklerinde ya da büyük ölçüde katılıyorum ve tamamen katılıyorum seçeneklerinde birlikte yoğunlaştığında; orta düzeyin altında (1ve 2) ve üstünde (4 ve 5) yer alan bu görüşler bazı maddelerde birleştirilerek analiz edilmiş ve birlikte yorumlanma yoluna gidilmiştir. Verilerin analizinde ve yorumlanmasında 0,01 ve 0,05 anlamlılık düzeyleri kabul edilmiştir. Verilerin analizi SPSS 11,5 paket programında gerçekleştirilmiştir.

\section{BULGULAR}

$\mathrm{Bu}$ bölümde ilk önce, öğretmen eğitimi programlarında; öğretimin planlanmas1, öğretme-öğrenme ve değerlendirme süreçlerindeki uygulamaların ne ölçüde yapılandırmacı yaklaşıma dayalı olarak gerçekleştirildiğine ilişkin öğretmen adaylarının görüşlerine yer verilmiş 
daha sonra da öğretmen adaylarının görüşlerinin, program ve cinsiyet değişkenlerine göre değişip değişmediği belirlenmeye çalışılmıştır.

\section{Öğretmen Adaylarının Yapılandırmacı Öğretime İlișkin Görüşleri}

Araştırmanın birinci sorusunu yanıtlamak için, öğretmen eğitim programlarında öğretimin; planlanması, öğretme-öğrenme ve değerlendirme süreçlerinin yapılandırmacı yaklaşıma dayalı gerçekleştirilip gerçekleştirilmediğine ilişkin öğretmen adaylarının görüşleri analiz edilmiştir. Yapılandırmacı öğretimin planlanmasına ilişkin görüşlerin dağılımı Tablo 2'de sunulmuştur.

Tablo 2. Öğretmen adaylarının öğretimin planlanmasına ilişkin görüşleri

\begin{tabular}{|c|c|c|c|c|c|c|c|c|c|c|}
\hline \multirow{2}{*}{$\begin{array}{l}\text { Öğretim elemanları öğretimi planlamada } \\
\text { nasıl bir yol izliyorlar? }\end{array}$} & \multicolumn{2}{|c|}{$* 5$} & \multicolumn{2}{|c|}{4} & \multicolumn{2}{|c|}{$J$} & \multicolumn{2}{|c|}{2} & \multicolumn{2}{|c|}{1} \\
\hline & $\mathrm{f}$ & $\%$ & $\mathrm{f}$ & $\%$ & $\mathrm{f}$ & $\%$ & $\mathrm{f}$ & $\%$ & $\mathrm{f}$ & $\%$ \\
\hline 1. Öğrencilerin görüşleri de alınıyor. & 12 & 3,7 & 52 & 15,9 & 108 & 32,9 & 86 & 26,2 & 70 & 21,3 \\
\hline Hed & 34 & 10,4 & 122 & 37,2 & 117 & 35,7 & 37 & 11,3 & 18 & 5,5 \\
\hline $\begin{array}{l}\text { eceklerinden } \\
\text { ecekleri }\end{array}$ & 13 & 4,0 & 62 & 18,9 & 134 & 40,9 & 88 & 26,8 & 31 & 9,5 \\
\hline en belirlenmesine özen & 18 & 5,5 & 96 & 29,3 & 131 & 39,9 & 66 & 20,1 & 17 & 5,2 \\
\hline $\begin{array}{l}\text { Öğretim etki } \\
\text { istek ve gerek } \\
\text { planlanıyor. }\end{array}$ & 12 & 3,7 & 42 & 12,8 & 103 & 31,4 & 111 & 33,8 & 60 & 18,3 \\
\hline anılması & 11 & 3,4 & 84 & 25,6 & 122 & 37,2 & 86 & 26,2 & 25 & 7,6 \\
\hline $\begin{array}{l}\text { Yeni } \\
\text { çaba g }\end{array}$ & 42 & 12,8 & 93 & 28,4 & 110 & 33,5 & 62 & 18,9 & 21 & 6,4 \\
\hline $\begin{array}{l}\text { amalarda ögrencilerin } \\
\text { ltusunda gerekli }\end{array}$ & 11 & 3,4 & 51 & 15,5 & 124 & 37,8 & 95 & 29,0 & 47 & 14,3 \\
\hline $\begin{array}{l}\text { Öğreno } \\
\text { aşamas } \\
\text { olanak }\end{array}$ & 12 & 3,7 & 62 & 18,9 & 101 & 30,8 & 108 & 32,9 & 45 & 13,7 \\
\hline $\begin{array}{l}\text { 10. Öğrencilerin ön öğrenmelerini } \\
\text { harekete geçirici etkinlikler planlan }\end{array}$ & 16 & 4,9 & 62 & 18,9 & 119 & 36,3 & 101 & 30,8 & 30 & 9,1 \\
\hline
\end{tabular}

* 5. Tamamen katılıyorum, 4. Büyük ölçüde katılıyorum, 3. Kısmen katılıyorum, 2. Çok az katılıyorum, 1. Hiç katılmıyorum

Tablo 2'de görüldüğü gibi, öğretmen adaylarının öğretimin planlanmasına ilişin görüşlere kısmen katılma oranlarının \% 30,8 ile \% 40,9 arasında değiştiği görülmektedir. Öğretmen adaylarının yaklaşık üçte biri öğretimin planlanması süreciyle ilgili bütün görüsslere kısmen katıldıklarını 
belirtmişlerdir. Öğretmen adaylarının öğretimin planlanmasına ilişkin görüşlere tamamen katılma ve büyük ölçüde katılma oranları birlikte ele alındığında; hedeflerin genel olarak belirlenmesi (\% 47,6), yeni teknolojilerin kullanılması için çaba gösterilmesi $(\% 41,2)$ ve konuların önceden belirlenmesine özen gösterilmesi (\% 34,8) ile ilgili davranışları öğretim elemanlarının tamamen gösterdikleri ve büyük ölçüde gösterdikleri yönünde görüş belirten öğretmen adaylarının oranları grubun üçte birinden biraz fazladır. Öğretmen adaylarının, hiç katılmadıkları ve çok az katıldıkları görüşler birlikte dikkate alındığında; öğretmen adaylarının \% 52,1'i, öğretim etkinliklerini öğrencilerin ilgi, istek ve gereksinimleri doğrultusunda planlama davranışını öğretim elemanlarının çok az gösterdikleri ve hiç göstermedikleri yönünde görüş belirtmişlerdir. Öğretmen adaylarının çok az katıldıkları ve hiç katılmadıkları görüşler birlikte incelendiğinde; öğretim elemanlarının; planlama sürecinde öğretmen adaylarının görüşlerini alma (\% 47,5) ve yapılan planlamalarda onların istekleri doğrultusunda gerekli değişiklikleri yapma (\% 43,3) davranışlarını çok az gösterdikleri ve hiç göstermedikleri yönünde görüş belirten öğretmen adaylarının oranları yarıya yakındır. Öğretmen adaylarının, öğretme-öğrenme süreçlerinde gerçekleştirilen uygulamalara ilişkin görüşleri Tablo 3'de sunulmuştur.

Tablo 3. Öğretmen adaylarının öğretme-öğrenme süreçlerine ilişkin görüşleri

\begin{tabular}{|c|c|c|c|c|c|c|c|c|c|c|}
\hline Öğret & & 5 & & 4 & & 3 & 2 & 2 & - & 1 \\
\hline süreçlerinde nasıl bir yol izliyorlar? & $\mathrm{f}$ & $\%$ & f & $\%$ & $\mathrm{f}$ & $\%$ & $\mathrm{f}$ & $\%$ & $\mathrm{f}$ & $\%$ \\
\hline $\begin{array}{l}\text { 1. Bilginin az miktarda ancak, } \\
\text { derinlemesine ögrenilmesine } \\
\text { önem veriliyor. }\end{array}$ & 11 & 3,4 & 46 & 14,0 & 141 & 43,0 & 100 & 30,5 & 30 & 9,1 \\
\hline $\begin{array}{l}\text { 2. Öğrenciler bilgileri kendileri } \\
\text { yapılandırıyorlar. }\end{array}$ & 20 & 6,1 & 95 & 29,0 & 107 & 32,6 & 79 & 24,1 & 27 & 8,2 \\
\hline $\begin{array}{l}\text { 3. Konular, yeri ve zamanı geldikçe } \\
\text { belirginleşiyor. }\end{array}$ & 21 & 6,4 & 112 & 34,1 & 128 & 39,0 & 61 & 18,6 & 6 & 1,8 \\
\hline $\begin{array}{l}\text { 4. Konular, öğrencilerin bireysel hız } \\
\text { ve yeteneklerine göre sarmal } \\
\text { olarak işleniyor. }\end{array}$ & 7 & 2,1 & 52 & 15,9 & 110 & 33,5 & 92 & 28,0 & 67 & 20,4 \\
\hline $\begin{array}{l}\text { 5. Öğrencilerin ön öğrenmeleriyle } \\
\text { yeni öğrenmeleri ilişkilendiriliyor. }\end{array}$ & 21 & 6,4 & 94 & 28,7 & 136 & 41,5 & 65 & 19,8 & 12 & 3,7 \\
\hline $\begin{array}{l}\text { 6. Öğrenciler birbirleriyle işbirliği } \\
\text { yaparak öğreniyorlar. }\end{array}$ & 36 & 11,0 & 110 & 33,5 & 116 & 35,4 & 51 & 15,5 & 15 & 4,6 \\
\hline $\begin{array}{l}\text { mokratik bir eğitim } \\
\text { şturuluyor. }\end{array}$ & 37 & 11,3 & 110 & 33,5 & 115 & 35,1 & 44 & 13,4 & 22 & 6,7 \\
\hline $\begin{array}{l}\text { 8. Öğrencilerin soru sorması teşvik } \\
\text { ediliyor. }\end{array}$ & 56 & 17,1 & 106 & 32,3 & 118 & 36,0 & 38 & 11,6 & 10 & 3,0 \\
\hline $\begin{array}{l}\text { 9. Öğrencilerin derslere etki } \\
\text { katılımı sağlanıyor. }\end{array}$ & 37 & 11,3 & 112 & 34,1 & 127 & 38,7 & 43 & 13,1 & 9 & 2,7 \\
\hline
\end{tabular}


10.Gerçek yaşam problemlerine dayalı ögrenme ortamları $\begin{array}{llllllllll}16 & 4,9 & 67 & 20,4 & 131 & 39,9 & 89 & 27,1 & 25 & 7,6\end{array}$ düzenleniyor.

11.Ögrenci merkezli, aktif ögrenmeyi sağlayan yöntemler uygulanıyor.

12.Derslerde çok çeşitli iletişim araçlarından yararlanılıyor.

13.Öğrencilere model davranışlar gösteriliyor.

14.Öğrencilere araştırma projeleri veriliyor.

15.Öğretim elemanları öğrencilerin öğrenmelerini kolaylaştırıcı davranışlar sergiliyorlar.

16.Alternatif görüşler sunarak öğrencilerin geniş bakış açısı kazanmalarına yardımcı oluyorlar.

17.Ögrencilerin birbirlerinin ögrenmelerini sağlamalarına yönelik etkinliklere yer veriliyor.

18. Öğretim elemanları öğrencilerle öğrenmeleri için hem sınıf içi hem $33 \quad 10,1 \quad 79 \quad 24,1 \quad 101 \quad 30,8 \quad 82 \quad 25,0 \quad 33 \quad 10,1$ sınıf dışında iletişim kuruyorlar.

19.Bilgilerin geniş ve farklı bakış açılarıyla öğrenilmesi

$\begin{array}{llllllllll}12 & 3,7 & 86 & 26,2 & 131 & 39,9 & 82 & 25,0 & 17 & 5,2\end{array}$ sağlaniyor.

20.Öğrencilerin doğal merakları destekleniyor ve araştırma yapmaya, keşfetmeye

$\begin{array}{llllllllll}26 & 7,9 & 96 & 29,3 & 113 & 34,5 & 76 & 23,2 & 17 & 5,2\end{array}$

$\begin{array}{llllllllll}28 & 8,5 & 58 & 17,7 & 106 & 32,3 & 106 & 32,3 & 30 & 9,1\end{array}$

$\begin{array}{llllllllll}14 & 4,3 & 64 & 19,5 & 124 & 37,8 & 100 & 30,5 & 26 & 7,9\end{array}$

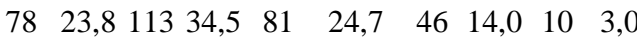

$\begin{array}{llllllllll}12 & 3,7 & 80 & 24,4 & 137 & 41,8 & 75 & 22,9 & 24 & 7,3\end{array}$

$\begin{array}{llllllllll}18 & 5,5 & 82 & 25,0 & 146 & 44,5 & 70 & 21,3 & 12 & 3,7\end{array}$

$\begin{array}{llllllllll}24 & 7,3 & 97 & 29,6 & 123 & 37,5 & 68 & 20,7 & 16 & 4,9\end{array}$ yöneltiliyorlar

21.Öğrencilerin öğrenme konularıyla ilgili olarak çevreleriyle etkileşim kurmaları sağlaniyor.

22.Öğrencilerin eleştirel düşünme becerileri geliştiriliyor.

23. Olayların yorumlanmasında basite indirgemek yerine, gerçek dünyanın karmaşıklığı göze önüne alınıyor.

24.Problem çözme becerileri geliştiriliyor.

$\begin{array}{llllllllll}20 & 6,1 & 88 & 26,8 & 137 & 41,8 & 62 & 18,9 & 21 & 6,4\end{array}$

$\begin{array}{llllllllll}29 & 8,8 & 79 & 24,1 & 130 & 39,6 & 66 & 20,1 & 24 & 7,3\end{array}$

$\begin{array}{llllllllll}21 & 6,4 & 76 & 23,2 & 138 & 42,1 & 76 & 23,2 & 17 & 5,2\end{array}$

$\begin{array}{llllllllll}22 & 6,7 & 90 & 27,4 & 129 & 39,3 & 70 & 21,3 & 17 & 5,2\end{array}$

25.Derslerde bilgileri ezberlemeye değil, kullanmaya önem

$\begin{array}{llllllllll}17 & 5,2 & 65 & 19,8 & 101 & 30,8 & 79 & 24,1 & 66 & 20,1\end{array}$ veriliyor.

26. Yaratıcılığı geliştirici etkinliklere yer veriliyor.

$\begin{array}{llllllllll}25 & 7,6 & 69 & 21,0 & 114 & 34,8 & 82 & 25,0 & 38 & 11,6\end{array}$

27.Öğrenme ortamında öğrenciler için günlük yaşantılardan, 
çevreden anlamlı örnekler

veriliyor.

28. Öğrenme ortamlarında

$\begin{array}{lllllllllll}\text { öğrencilerin farklı yaklaşımları } & 23 & 7,0 & 66 & 20,1 & 150 & 45,7 & 70 & 21,3 & 19 & 5,8\end{array}$

kabulleniliyor ve teşvik ediliyor.

29.Öğrenciler; bilgileri

sinıflandırmaya, analiz etmeye,

tahmin etmeye, yaratmaya

$\begin{array}{llllllllll}21 & 6,4 & 77 & 23,5 & 118 & 36,0 & 87 & 26,5 & 25 & 7,6\end{array}$

yönlendiriliyor.

30.Sınıftaki her öğrencinin duygu

ve düşüncelerini, inanç ve tutumlarını anlamaya

$\begin{array}{llllllllll}19 & 5,8 & 59 & 18,0 & 105 & 32,0 & 88 & 26,8 & 57 & 17,4\end{array}$

çalışıyorlar.

31.Sınıfta çeşitli tartışma tekniklerine yer veriliyor.

32.Öğrencilerin bilgileri sorgulamaları sağlanıyor.

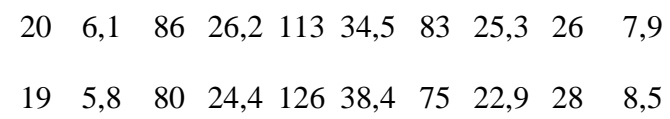

33.Öğrencilerin öğrenilen bilgileri yeni durumlarda kullanmalarına olanak veriliyor.

34.Öğrencilerin kendilerine özgü özellikleri ortaya koymalarına önem veriliyor.

35.Öğrencilerin girişimcilik gücü geliştiriliyor.

36.Öğrencilere çok yönlü uyarıcilar sunuluyor.

37.Öğrencilere kendi ögrenmelerinin sorumluluğu veriliyor.

38.Öğrenme ortamlarında öğrenciler birbirleriyle ve ögretim elemanlarıyla rahatça iletişim kurabiliyorlar.

39. Öğrenciler, öğrenmeyi okul dışında da etkin biçimde sürdürmeleri yönünde

$\begin{array}{llllllllll}15 & 4,6 & 85 & 25,9 & 127 & 38,7 & 85 & 25,9 & 16 & 4,9\end{array}$

$\begin{array}{llllllllll}15 & 4,6 & 85 & 25,9 & 127 & 38,7 & 85 & 25,9 & 16 & 4,9\end{array}$

$\begin{array}{llllllllll}9 & 2,7 & 67 & 20,4 & 128 & 39,0 & 95 & 29 & 29 & 8,8\end{array}$

$\begin{array}{llllllllll}19 & 5,8 & 76 & 23,2 & 118 & 36,0 & 87 & 26,5 & 28 & 8,5\end{array}$

$\begin{array}{llllllllll}13 & 4,0 & 57 & 17,4 & 123 & 37,5 & 105 & 32,0 & 30 & 9,1\end{array}$

$\begin{array}{llllllllll}50 & 15,2 & 109 & 33,2 & 110 & 33,5 & 51 & 15,5 & 8 & 2,4\end{array}$

$\begin{array}{llllllllll}59 & 18,0 & 108 & 32,9 & 96 & 29,3 & 49 & 14,9 & 16 & 4,9\end{array}$ yüreklendiriliyor.

Tablo 3 incelendiğinde, öğretme-öğrenme süreçlerinde gerçekleştirilen uygulamalara ilişkin olarak öğretmen adaylarının büyük ölçüde katıldıkları görüşlerin \% 32,3 ile \% 34,1 oranları arasında olduğu görülmektedir. Öğretmen adaylarının yaklaşık üçte biri; öğrencilere araştırma projeleri verilmesi, öğrenme ortamlarında öğrencilerin birbirleriyle ve öğretim elemanlarıyla rahatça iletişim kurmalarının sağlanması, öğrencilere kendi öğrenmelerinin sorumluluğunun verilmesi, konuların yeri ve zamanı geldikçe belirginleşmesi, öğrencilerin derslere etkin katılımının sağlanması, 
öğrencilerin birbirleriyle işbirliği yaparak öğrenmeleri, sınıfta demokratik eğitim ortamının oluşturulması ve soru sormanın teşvik edilmesi davranışlarının büyük ölçüde gösterildiği yönünde görüş belirtmiştir.

Öğretmen adaylarının öğretme-öğrenme süreçlerine ilişkin hiç katılmadıkları ve çok az katıldıkları görüşler birlikte düşünüldügünde; konuların öğrencilerin bireysel hız ve yeteneklerine göre sarmal olarak işlenmesi (\% 48,4); derslerde bilgilerin ezberlenmesine değil, kullanılmasına önem verilmesi (\% 44,2); öğretim elemanlarının sınıftaki her öğrencinin duygu ve düşüncelerini, inanç ve tutumlarını anlamaya çalışmaları $(\% 44,2)$; bilginin az miktarda ancak, derinlemesine öğrenilmesine önem verilmesi (\% 39,6); öğrencilere çok yönlü uyarıcıların sunulması (\% 41,1) davranışlarını öğretim elemanlarının hiç göstermedikleri ve çok az gösterdikleri yönünde görüş belirten öğretmen adaylarının oranlarının yarıya yakın olduğu görülmektedir. Öğretmen adaylarının öğretimin değerlendirilmesine ilişkin görüşleri Tablo 4'te sunulmuştur.

Tablo 4. Öğretmen adaylarının değerlendirme sürecine ilişkin görüşleri

\begin{tabular}{|c|c|c|c|c|c|c|c|c|c|c|}
\hline \multirow{2}{*}{$\begin{array}{l}\text { Öğretim elemanları değerlendirme } \\
\text { süreçlerinde nasıl bir yol izliyorlar? }\end{array}$} & 5 & 4 & 3 & 2 & 1 & & & & & \\
\hline & $\mathrm{f}$ & $\%$ & $\mathrm{f}$ & $\%$ & $\mathrm{f}$ & $\%$ & $\mathrm{f}$ & $\%$ & $\mathrm{f}$ & $\%$ \\
\hline $\begin{array}{l}\text { 1. Ölçme ve değerlendirme ölçütlerini, } \\
\text { öğretim elemanları ve öğrenciler } \\
\text { birlikte belirliyorlar. }\end{array}$ & 7 & 2,1 & 18 & 5,5 & 69 & 21,0 & 88 & 26,8 & 146 & 44,5 \\
\hline $\begin{array}{l}\text { 2. Öğrencilerin değerlendirilmesinde } \\
\text { öğrenme süreci ön planda tutuluyor. }\end{array}$ & 12 & 3,7 & 53 & 16,2 & 112 & 34,1 & 96 & 29,3 & 55 & 16,8 \\
\hline $\begin{array}{l}\text { 3. İşbirlikli grup çalışmaları } \\
\text { değerlendiriliyor. }\end{array}$ & 33 & 10,1 & 92 & 28,0 & 109 & 33,2 & 74 & 22,6 & 20 & 6,1 \\
\hline $\begin{array}{l}\text { 4. Öğrencilerin değerlendirilmesinde } \\
\text { sınıf içindeki etkileşim durumları göz } \\
\text { önüne alınıyor. }\end{array}$ & 9 & 2,7 & 62 & 18,9 & 90 & 27,4 & 109 & 33,2 & 58 & 17,7 \\
\hline $\begin{array}{l}\text { 5. Öğrencilerin yaptığı her ürün (ödev, } \\
\text { proje, rapor vb.) değerlendirmeye } \\
\text { alınıyor. }\end{array}$ & 80 & 24,4 & 100 & 30,5 & 95 & 29,0 & 39 & 11,9 & 14 & 4,3 \\
\hline $\begin{array}{l}\text { 6. Öğretim elemanları öğrencileri çok } \\
\text { çeşitli ölçme araçları (gözlem, kişisel } \\
\text { görüşme, açık uçlu sorular, gelişim } \\
\text { dosyası vb.) kullanarak } \\
\text { değerlendiriyorlar. }\end{array}$ & 15 & 4,6 & 60 & 18,3 & 95 & 29,0 & 86 & 26,2 & 72 & 22,0 \\
\hline $\begin{array}{l}\text { 7. Öğrencilerin birbirlerini } \\
\text { değerlendirmelerine olanak veriliyor. }\end{array}$ & 7 & 2,1 & 34 & 10,4 & 98 & 29,9 & 95 & 29,0 & 94 & 28,7 \\
\hline $\begin{array}{l}\text { 8. Öğrencilerin kendi kendilerini } \\
\text { değerlendirmelerine olanak veriliyor. }\end{array}$ & 7 & 2,1 & 48 & 14,6 & 90 & 27,4 & 90 & 27,4 & 93 & 28,4 \\
\hline $\begin{array}{l}\text { 9. Öğrencilerin yaptıkları hatalar, } \\
\text { ögrenmeleri için bir firsat olarak } \\
\text { kullanılıyor. }\end{array}$ & 20 & 6,1 & 52 & 15,9 & 114 & 34,8 & 85 & 25,9 & 57 & 17,4 \\
\hline $\begin{array}{l}\text { 10.Öğrenciler öğretim etkinliklerini } \\
\text { değerlendirebiliyorlar. }\end{array}$ & 21 & 6,4 & 45 & 13,7 & 120 & 36,6 & 85 & 25,9 & 57 & 17,4 \\
\hline
\end{tabular}


Öğretmen adaylarının değerlendirme sürecine ilişkin görüşlere tamamen ve büyük ölçüde katılma oranları birlikte ele alındığında; grubun yarıdan biraz fazlası $(\%$ 54,9) öğretim elemanlarının, öğrencilerin yaptığı her ürünü (ödev, proje, rapor vb.) tamamen ve büyük ölçüde değerlendirdiklerini; öğretmen adaylarının üçte biri, işbirlikli grup çalışmalarının tamamen ve büyük ölçüde değerlendirildiği (\% 38) yönünde görüş belirtmişlerdir. Grubun yaklaşık yarısı (\% 44,5) ölçme ve değerlendirme ölçütlerini, öğretim elemanları ve öğrencilerin hiç birlikte belirlemediklerini; grubun üçte biri kadarı $(\% 26,8)$ ise çok az birlikte belirlediklerini belirtmişlerdir. Öğretmen adaylarının çok az katıldıklarını ve hiç katılmadıklarını belirttikleri görüşler birlikte incelendiğinde; grubun yarıdan fazlası, öğrencilerin birbirlerini değerlendirmelerine $(\% 57,7)$ ve kendi kendilerini değerlendirmelerine olanak verilmesi (\% 55,8); öğrencilerin değerlendirilmesinde sınıf içindeki etkileşim durumlarının göz önüne alınması (\% 50,9) davranışlarının çok az gösterildiği ve hiç gösterilmediği yönünde görüşler belirtmişlerdir.

\section{Öğretmen Adaylarının Program ve Cinsiyetlerine Göre Görüşleri}

Araştırmanın ikinci sorusunu yanıtlamak için önce, öğretmen adaylarının görüşlerine ilişkin varyansların homojenliği Levene testi ile kontrol edilmiştir. Bu teste göre, varyansların homojen olduğu görülerek tek yönlü varyans analizi (ANOVA) yapılmış ve analiz sonuçları Tablo 5'de sunulmuştur.

Tablo 5. Öğretmen adaylarının planlama, öğretme öğrenme ve değerlendirme süreçlerine ilişkin görüşlerinin programlarına göre varyans analizi sonuçları

\begin{tabular}{|c|c|c|c|c|c|c|c|}
\hline Süreçler & $\begin{array}{l}\text { Varyansın } \\
\text { Kaynağı }\end{array}$ & $\begin{array}{c}\text { Kareler Toplamı } \\
\text { (KT) }\end{array}$ & $\begin{array}{c}\text { Serbestlik } \\
\text { Derecesi } \\
\text { (sd) }\end{array}$ & $\begin{array}{c}\text { Kareler } \\
\text { Ortalaması } \\
(\mathrm{KO})\end{array}$ & $\mathrm{F}$ & $\mathrm{p}$ & $\begin{array}{c}\text { LSD } \\
\text { Fark Ortalamas1 }\end{array}$ \\
\hline Planlama & $\begin{array}{l}\text { Gruplararası } \\
\text { Gruplariçi } \\
\text { Toplam }\end{array}$ & $\begin{array}{r}732,038 \\
13191,523 \\
13923,561\end{array}$ & $\begin{array}{c}6 \\
321 \\
327\end{array}$ & $\begin{array}{r}122,006 \\
41,095\end{array}$ & 2,969 & $0,008^{*}$ & $\begin{array}{c}* * 1<4(2,76) \\
1<6(2,89) \\
3<4(3,38) \\
3<6(3,51) \\
3<7(3,75) \\
5<6(2,66)\end{array}$ \\
\hline $\begin{array}{l}\text { Öğretme- } \\
\text { öğrenme }\end{array}$ & $\begin{array}{l}\text { Gruplararası } \\
\text { Gruplariçi } \\
\text { Toplam }\end{array}$ & $\begin{array}{r}12845,685 \\
187839,425 \\
200685,110\end{array}$ & $\begin{array}{c}6 \\
321 \\
327\end{array}$ & $\begin{array}{r}2140,948 \\
585,170\end{array}$ & 3,659 & $0,002^{*}$ & $\begin{array}{l}1<6(3,75) \\
2<6(6,84) \\
4<6(4,33)\end{array}$ \\
\hline Değerlendirme & $\begin{array}{l}\text { Gruplararası } \\
\text { Gruplariçi } \\
\text { Toplam }\end{array}$ & $\begin{array}{r}1141,666 \\
19275,965 \\
20417,631\end{array}$ & $\begin{array}{c}6 \\
321 \\
327\end{array}$ & $\begin{array}{r}190,278 \\
60,050\end{array}$ & 3,169 & $0,005^{*}$ & $\begin{array}{l}1<2(2,15) \\
1<4(1,32) \\
1<5(1,57) \\
1<6(1,20) \\
\end{array}$ \\
\hline $\begin{array}{l}* \mathrm{p}<0,01 \\
* * 1 . \text { Sinıf Öğre } \\
\text { Öğretmenliğ } \\
\text { Öğretmenliğ }\end{array}$ & $\begin{array}{l}\text { etmenliği, 2.S } \\
\text { i, 5.Bilgisaya }\end{array}$ & $\begin{array}{l}\text { yal Bilgiler } \\
\text { ve Öğretim }\end{array}$ & $\begin{array}{l}\text { Ötmenliği, } \\
\text { Ögretm }\end{array}$ & $\begin{array}{r}\text { 3.Matematik } \\
\text { enliği, 6.İngil }\end{array}$ & $\begin{array}{l}\text { Öğretn } \\
\text { zce Öğg }\end{array}$ & $\begin{array}{l}\text { nenliği, } \\
\text { retmenli }\end{array}$ & $\begin{array}{rr}\text { 4. } & \text { Okulöncesi } \\
\text { iği, } & \text { 7.Fransızca }\end{array}$ \\
\hline
\end{tabular}


Öğretmen adaylarının, öğretimin planlanması $\left[\mathrm{F}_{(6-321)}=2,97 ; \mathrm{p}<0,01\right]$; öğretme-öğrenme $\left[\mathrm{F}_{(6-321)}=3,66 ; \mathrm{p}<0,01\right]$ ve değerlendirme $\left[\mathrm{F}_{(6-321)}=3,17\right.$; $\mathrm{p}<0,01]$ süreçlerine ilişkin görüşleri arasında öğrenim gördükleri programlara göre anlamlı farklar bulunmuştur. $\mathrm{Bu}$ farkların kaynağını saptamak için yapılan LSD testinin sonuçlarına göre; öğretimin planlanmasına ilişkin farkın; Sınıf Öğretmenliği $(\bar{X}=27,31)$ ile Okul Öncesi Öğretmenliği $(\bar{X}=30,07)$ ve İngilizce Öğretmenliği $(\bar{X}=30,20)$; Matematik öğretmenliği $(\bar{X}=26,69)$ ile İngilizce $(\bar{X}=30,20)$, Fransizca $(\bar{X}=30,44)$ ve Okul öncesi ( $\bar{X}=30,07)$ Öğretmenliği; İngilizce Öğretmenliği $(\bar{X}=30,20)$ ile BÖTE Öğretmenliği $(\bar{X}=27,54)$ programlarındaki öğretmen adaylarının görüşleri arasında anlamlı olduğu görülmüştür. Öğretme-öğrenme süreçlerine ilişkin olarak; İngilizce Öğretmenliği $(\bar{X}=127,57)$ ile Sınıf Öğretmenliği $(\bar{X}=110,47)$, Sosyal Bilgiler Öğretmenliği $(\bar{X}=113,27)$ ve Okul Öncesi Eğitimi Öğretmenliği $(\bar{X}=117,72)$ öğretmen adaylarının görüşleri arasında anlamlı fark bulunmuştur. Değerlendirme sürecine ilişkin olarak; Sınıf Öğretmenliği $(\bar{X}=26,72)$ ile Sosyal Bilgiler Öğretmenliği $(\bar{X}=31,40)$, Okul Öncesi Eğitimi Öğretmenliği $(\bar{X}=30,02), \quad$ BÖTE Öğretmenliği $(\bar{X}=31,21)$ ve İngilizce Öğretmenliği $\quad(\bar{X}=30,88)$ programlarındaki öğretmen adaylarının görüşleri arasında anlamlı fark bulunmuştur.

Öğretmen adaylarının görüşleri arasında cinsiyete göre anlamlı bir fark olup olmadığını belirlemek amacı ile yapılan bağımsız gruplar t testi sonuçları Tablo 6'da sunulmuştur.

Tablo 6. Öğretmen adaylarının planlama, öğretme -öğrenme ve değerlendirme süreçlerine ilişkin görüşlerinin cinsiyete göre " $t$ " testi analizi

\begin{tabular}{llrccccc}
\hline \multicolumn{1}{c}{ Süreçler } & Cinsiyet & \multicolumn{1}{c}{$\mathrm{N}$} & $\overline{\mathrm{X}}$ & $\mathrm{s}$ & $\mathrm{sd}$ & $\mathrm{t}$ & $\mathrm{p}$ \\
\hline Planlama & K1z & 240 & 28,68 & 6,39 & 326 & 0,634 & 0,41 \\
& Erkek & 88 & 28,16 & 6,90 & & & \\
Öğretme- & Kız & 240 & 118,24 & 25,13 & 326 & 0,093 & 0,73 \\
öğrenme & Erkek & 88 & 117,95 & 23,92 & & & \\
Değerlendirme & K1z & 240 & 26,19 & 6,89 & 326 & - & 0,12 \\
& Erkek & 88 & 26,84 & 7,81 & & 0,734 & \\
\hline
\end{tabular}

Tablo 6'da da görüldüğü gibi öğretmen adaylarının planlama $\left[\mathrm{t}_{(326)}=0,63, \quad \mathrm{p}>0,05\right], \quad$ öğretme-öğrenme $\left[\mathrm{t}_{(326)}=0,09, \quad \mathrm{p}>0,05\right] \quad$ ve değerlendirme $\left[\mathrm{t}_{(326)}=0,73, \mathrm{p}>0,05\right]$ süreçlerine ilişkin görüşleri arasında cinsiyete göre anlamlı bir fark yoktur. 


\section{TARTIŞMA ve SONUÇ}

Araştırma bulgularına göre, öğretmen eğitim programlarında öğretmen adaylarının yaklaşık üçte biri; planlama, öğretme-öğrenme ve değerlendirme süreçleriyle ilgili görüşlerin hemen hemen tamamına kısmen katıldıklarını belirtmişlerdir. Görüşlere, tamamen katılan ve büyük ölçüde katılanların oranı grubun üçte birinden daha azdır. Görüşlere, çok az katılan ve hiç katılmayanların oranı da ayrı ayrı incelendiğinde, bu oranların da grubun üçte birinden az olduğu görülmektedir. Öğretmen adaylarının görüşlerine göre, öğretim süreçlerinde; yapılandırmacı ilke ve yöntemlerin kısmen gerçekleştirilebildiği ancak, tam olarak gerçekleştirilemediği söylenebilir.

Öğretmen adayları öğretimin planlanması sürecindeki görüşlere genel olarak kısmen katılmışlardır. Planlama sürecinde; hedeflerin genel olarak belirlendiği, yeni teknolojilerin kullanılması için çaba gösterildiği ve konuların önceden belirlenmesine özen gösterildiği görüşlerine, grubun üçte birinden biraz fazlası, tamamen ve büyük ölçüde katıldıklarını belirtmişlerdir. Öğretimin planlanmasında, bu yapılandırmacı özelliklerin kısmen gerçekleştirildiği ancak, tam olarak sağlanamadığı anlaşılmaktadır. Ayrıca, öğretim etkinliklerinin öğrencilerin ilgi, istek ve gereksinimleri doğrultusunda planlandığ 1 görüşüne çok az katılan ve hiç katılmayanların oranının grubun yarısı olması dikkat çekicidir. Bununla birlikte, öğretmen adaylarının yaklaşık yarıya yakınının, planlama sürecinde, görüşlerinin alındığ 1 ve istekleri doğrultusunda planlarda gerekli değişikliklerin yapıldığına çok az katıldıkları ve hiç katılmadıkları da göz önüne alındığında; öğretimin planlanmasında, öğretmen adaylarının görüşlerinin, ilgi, istek ve gereksinimlerinin pek dikkate alınmadığı düşünülebilir. Niemi'nin (2002) araştırmasında da benzer bulgular elde edilmiş, öğretmen eğitimi öğrencilerinin kendi öğrenme görevlerini ve ortamlarını planlama ve oluşturma olanağını çok az bulduklarını belirtmişlerdir. Oysa yapılandırmacı öğrenme ortamlarında, planların öğrencilerle birlikte; seçenekli, çok boyutlu ve esnek biçimde hazırlanması (Sönmez, 2004) ve öğrencilere öğrenme kararlarının alınmasında sorumluluk verilmesi gerekmektedir (Airasian ve Walsh, 1997).

Yapılandırmacı sınıflarda öğrencilerin kendi kararlarını verebilmeleri, kendi öğrenme planlarını yapıp uygulayabilmeleri gerektiği (Gagnon ve Collay, 2001) göz önüne alındığında; öğretimin planlanması sürecinde önemli yetersizlikler olduğu söylenebilir. Bu bulgular, Kesal'ın (2003) araştırmasındaki, öğrenme etkinliklerinin planlanmasında İngilizce Öğretmenliği öğrencilerinin katkılarının sınırlı olduğuna ilişkin bulgularla da benzerlik göstermektedir. $\mathrm{Bu}$ durum, öğretim elemanlarının, öğretmen adaylarının özelliklerini yeterince tanımamalarından ve ögretimi kendilerine 
göre planlamalarından kaynaklanmış olabilir. Yapılandırmacı sınıf ortamında öğretmenlerin, öğrencilerin ön öğrenme ve yaşantılarını tanımaları ve etkinlikleri buna göre planlamaları gerekmektedir. Öğrenme ortamında, seçilebilecek etkinlikler ve ögretim materyalleri bulunması durumunda, öğrenci kendi gelişim düzeyine ve ilgisine en uygun olanını özgürce seçebilir ve öğrenmeye güdülenebilir (Senemoğlu, 2004). Aksi durumda, var olan ön bilgilerini yeni bilgilerle bütünleştirmekte güçlük çeker, iyi bir performans gösteremez. Kısacas1, böyle bir ortamda, öğrenmeyi kendisine özgü biçimde yapılandırması beklenemez.

Öğretmen adaylarının öğretme-öğrenme süreciyle ilgili görüşleri incelendiğinde; grubun yaklaşı üçte biri öğretme-öğrenme süreciyle ilgili bazı görüşlere $(2,3,6,7,8,9,11)$ büyük ölçüde katılmışlardır. Buna göre, öğrencilere; araştırma projelerinin verilmesi, öğrenme ortamlarında öğrencilerin birbirleriyle ve öğretim elemanlarıyla rahatça iletişim kurabilmeleri, kendi öğrenmelerinin sorumluluğunun verilmesi; konuların yeri ve zamanı geldikçe belirginleşmesi; öğrencilerin derslere etkin katılımının sağlanması ve birbirleriyle işbirliği yaparak öğrenmeleri, sınıfta demokratik eğitim ortamının oluşturulması ve öğrencilerin soru sormalarının teşvik edilmesi ile ilgili yapılandırmacı uygulamaların öğretmen eğitimi programlarında yer aldığını; ancak, öğretmen adaylarının yalnız üçte birinin bu uygulamaların büyük ölçüde gösterildiği görüşünde olması bu uygulamaların çok yeterli olmadığını düşündürmektedir. Ayrıca, öğretmeöğrenme süreçleriyle ilgili bazı görüşlere $(1,4,25,30,36)$ hiç katılmadıklarını ve çok az katıldıklarını belirtenlerin oranlarının grubun yarısına yakın olduğu ve grubun üçte birinden fazlasının bir madde (14) dışında bütün maddelere orta düzeyde katıldığı görülmektedir. Araştırmada, konuların öğrencilerin bireysel hız ve yeteneklerine göre, sarmal olarak işlendiği görüşüne öğretmen adaylarının çok az düzeyde katılmaları ise, bu noktada daha fazla yetersizliğin olduğunu düşündürmektedir. Öğretmen adaylarının görüşlerine göre, öğretme-öğrenme süreçlerinde yapılandırmac1 uygulamaların kısmen gerçekleştirildiği söylenebilir.

Araştırma bulgularına göre, öğretme-öğrenme süreçlerinin yapılandırmacı anlayışla gerçekleştirilmesinde birtakım çabaların olduğu, ancak, bunların yeterli düzeyde olmadığı anlaşılmaktadır. $\mathrm{Bu}$ durum, geleneksel, öğretmen merkezli yaklaşımdan tam olarak vazgeçilmemesinden kaynaklanmış olabilir. Niemi'nin (2002) araştırmasında da benzer şekilde; etkin öğrenmenin birçok göstergesi olmakla birlikte; öğretim yöntemlerinin pasif olduğu, ders içeriklerinin yaşamla bağlantısının olmadığı, kuram ve uygulamanın birbirinden uzak olduğu bulguları elde edilmiştir. Oysa Yanpar Şahin'in (2003) araştırmasında olduğu gibi, yapılandırmacı yaklaşımın 
kullanıldığı öğrenme ortamında öğrencilerin olumlu etkiler algılamaları ve etkin öğrenmenin önemini yansıtmaları beklenir. Yapılandırmacı yaklaşımla eğitim alan öğrencilerin öğrenme-öğretme sürecine ilişkin algılarının farklılaştığı görülmüştür (Al-Weher, 2004). Rainer ve Guyton'un (1999) araştırmasında da öğretmen eğitiminde gerçekleştirilen model yapılandırmacı rollerin ve demokratik uygulamaların öğretmenlerin sınıflarında bunları kullanmalarını etkilediği belirtilmektedir. Öğrenci merkezli planlamalar ve etkinlikler, hizmet öncesinde ögretmen adaylarını geleceğe hazırladığından (Hewett, 2003) hizmet öncesi öğretmen eğitiminde gözlenen bu yetersizliklerin giderilmesi gerekmektedir.

Öğretmen adaylarının, öğretimin değerlendirilmesi sürecine ilişkin görüşleri incelendiğinde; görüşlerin çoğuna $(1,3,5,6,8,9,10)$ çok az katıldıklarını ve hiç katılmadıklarını belirtenlerin oranı, grubun üçte birinden fazlasını oluşturmaktadır. Bununla birlikte, değerlendirme ile ilgili olarak tüm görüşlere kısmen katıldıklarını belirtenlerin oranı da grubun üçte biri olduğu görülmektedir. Değerlendirmede, öğretmen adaylarının; sınıf içi etkileşimlerinin dikkate alınması ve ölçütlerin belirlenmesine katılımlarının sağlanması; çeşitli araç ve yöntemlere yer verilmesi görüşlerine çok az düzeyde katılmaları bu noktalarda önemli yetersizlikler olduğuna dikkat çekmektedir. Çünkü, yapılandırmacı eğitim programında değerlendirme, öğretmen ve öğrencilerle birlikte planlanan ve yürütülen; öğrenme süreci ile birlikte devam eden ve ögretime yön veren bir süreçtir (Koç ve Demirel, 2006).

Öğretmen adaylarına sınıfta; gelişim dosyaları, dereceleme ölçekleri vb. gibi alternatif değerlendirme tekniklerinin nasıl kullanılabileceğini öğretmek önem taşımaktadır (Casas, 2004). Bunun en iyi yolu ise, bu teknikleri öğretmen eğitiminde kullanarak onların yaşantılar geçirmelerini sağlamaktır. Ancak bulgulara göre, değerlendirme süreçlerinde yapılandırmacı ilkelerin tam olarak uygulanamadığı anlaşılmaktadır. Bu bulgular bazı araştırma bulgularını da desteklemektedir. Örneğin, Kesal'ın (2003) araştırmasında, sınavlarla ilgili olarak öğrencilerle görüş alışverişinde bulunulmasının nadiren olduğunu ve değerlendirme stratejilerinin düzenlenmesinde öğrencilerin katkılarının az olduğunu; Kesal ve Aksu'nun (2006) araştırmasında da, gelişim dosyası hazırlamanın en az sıklıkta kullanıldığını belirten benzer bulgular elde edilmiştir. Oysa yapılandırmacı yaklaşımda değerlendirme, gelişim dosyası gibi çok çeşitli ölçme araç ve yöntemlerini kullanmayı gerektirir.

Öğretmen adaylarının; planlama, öğretme-öğrenme ve değerlendirme süreçleriyle ilgili görüşleri arasında öğrenim gördükleri programlara göre anlamlı fark vardır. Bu farkın, öğretmenlik programlarında farklı ögrenme ve 
değerlendirme yaklaşımları ve modelleri uygulanmasından ve programlarda dersleri yürüten öğretim elemanlarının özelliklerinden kaynaklanmış olabileceği söylenebilir. Öğretmen adaylarının görüşleri arasında cinsiyete göre anlamlı fark bulunmamıştır. Diğer bir deyişle, görüssler cinsiyete göre farklılaşmamaktadır. Bu bulgu Kesal ve Aksu'nun (2006) araştırmasındaki öğrencilerin algılamalarının cinsiyete göre değiştiği bulgusunu desteklememektedir.

Sonuç olarak, öğretmen adaylarının görüşlerine göre, öğretmen eğitim programlarında yapılandırmacı öğrenme ortamlarının tam olarak ya da büyük ölçüde gerçekleştirildiği söylenemez. Öğretmen eğitim programlarında, öğretimin planlanmasının öğretmen adaylarının katılımıyla, ilgi ve gereksinimleri dikkate alınarak yapılandırmacı anlayışla gerçekleştirilmesine önem verilmelidir. Yapılandırmacı öğrenme ortamı oluşturmak için; etkin öğrenme etkinliklerinden, birincil kaynaklardan ve yeni teknolojilerden yararlanılmalı öğretmen adaylarına gerçek yaşam deneyimleri kazandırılmalıdır. Değerlendirme, öğrenme sürecinin her aşamasında, çeşitli ölçme araç ve yöntemleriyle yapılmalı; bu sürece, öğretmen adaylarının katılımı sağlanmalı; kendisini, arkadaşlarını ve öğretim elemanlarını değerlendirebilme olanakları verilmelidir. Ancak öncelikle, öğretmen adaylarına yapılandırmacılık ilkelerinin nasıl uygulanabileceği ile ilgili model davranışlar gösterilmelidir. Bununla birlikte, yapılandırmacı öğrenme ortamlarını oluşturabilmek için, öğretmen eğitimi programlarının da yapılandırmacı yaklaşım doğrultusunda geliştirilmesi gerekmektedir. Böylece, öğrenci merkezli, etkin, yapılandırmacı öğrenme ortamlarında yetiştirilen öğretmen adayları, gerekli yeterlikleri kazanarak gelecekte yapılandırmacı öğrenme ortamlarını düzenleyebilirler. 


\section{KAYNAKLAR}

Airasian, P. W. \& Walsh, M. E. (1997). Constructivist cautions. Phi Delta Kapan, 78(6), 444-449.

Akar, H. ve Yıldırım, A. (2004). Oluşturmacı öğretim etkinliklerinin sınıf yönetimi dersinde kullanılması: bir eylem araştırması. Sabancı Üniversitesi Iyi Örnekler Konferansl. [Online]: http://www.erg.sabanciuniv.edu/iok2004/bildiriler/Ali\%20Yildirim.doc adresinden 27.01. 2006 tarihinde indirilmiştir.

Akgün, Ö. E. (2005). Uygulayanların deneyim ve görüşleriyle yapıcı yaklaşım ve yapıcı yaklaşımların uygulanması öncesinde yapılması önerilen araştırmalar. Yüzüncüyıl Üniversitesi, Elektronik Ĕgitim Fakültesi Dergisi, 2(2). 13.02.2008 tarihinde ulaşıld,, [Online]: http://efdergi.yyu.edu.tr/makaleler/cilt_II/ozcan_akgun2.doc.

Al -Weher, M. (2004). The effect of a training course based on constructivism on student teachers' perceptions of the teaching/learning process. Asia-Pacific Journal of Teacher Education, 32 (2), 169-184.

Arslan, M. (2007). Eğitimde yapılandırmacı yaklaşımlar. Ankara Üniversitesi Eğitim Bilimleri Fakültesi Dergisi, 40(1), 41-61.

Austin, L. (2004). A constructivist approach to facilitating intrapersonal change in pre-service teachers. College Student Journal, 38(2), 309313.

Berry, A. \& Loughran J. J. (2002). Developing an understanding of learning to teach in teacher education. In J. Loughran \& T. Russell (Eds.), Improving Teacher Education Practices Through Self-Study (pp. 1329). London: Routledge Falmer.

Bevevino, M. M.; Dengel, J., \& Adams, K. (1999). Constructivist theory in the classroom onternalizing concepts through inquiry learning. The Clearing House, 72(5), 275-278.

Bıkmaz, F. H. (2006). Yeni ilköğretim programları ve öğretmenler. Ankara Üniversitesi Ë̆itim Bilimleri Fakültesi Dergisi, 39(1), 99-116.

Brooks, M. G. \& Brooks, J. G. (1999). The constructivist classroom: The courage to be constructivist. Educational Leadership, 57(3), 18-24.

Brown, J. C. \& Adams, A. (2001). Constructivist teaching strategies: Projects in teacher education. Springfield, Illinois, USA: Charles C. Thomas Publisher, Ltd.

Can, T. (2004). Yabancl dil olarak İngilizce öğretmenlerinin yetiştirilmesinde kuram ve uygulama boyutuyla oluşturmacı yaklaşım. Yayımlanmamış yüksek lisans tezi. İstanbul Üniversitesi, Sosyal Bilimler Enstitüsü, İstanbul.

Carlson, H. L. (1999). From practice to theory: A social constructivist approach to teacher education. Teachers and Teaching: Theory and Practice, 5(2), 203-218. 
Casas, M. (2004). Making pedagogical theory come alive. The Teacher Educator, 39(3), 170-183.

Cochran-Smith, M. (2001). Constructing outcomes in teacher education: Policy, practice and pitfalls. Education Policy Analysis Archives, 9 (11), 1-68.

Cohen, L., Manion, L. \& Morrison, K. (2005). Research methods in education. (5th Ed.) London: Routledge, Falmer.

Cook, L. S., Smagorinsky, P., Fry, P.G., Konopak, B. \& Moore, C. (2002). Problems in developing a constructivist approach to teaching: one teacher's transition from teacher preparation to teaching. The Elementary School Journal, 102 (5), 389-413.

Demirel, Ö. (2006). Kuramdan uygulamaya eğitimde program geliştirme. (9. Bask1). Ankara: Pegem A Yayıncılık.

Deryakulu, D. (2000). Yapıcı öğrenme, A. Şimşek (Edt.) Sinıfta Demokrasi (ss.53-77). Ankara: Eğitim -Sen Yayınları.

Gagnon, G. W. \& Collay, M. (2001). Designing for learning six elements in constructivist classrooms. Thousand Oaks, California: Corwin Pres, Inc.

Goubeaud, K. \& Yan, W. (2004). Teacher educators' teaching methods, assessments and grading: A comparison of higher education faculty's instructional practices. The Teacher Educator, 40(1), 1-16.

Gökalp, M. (2004). Türkiye'deki öğretmenlerin meslek bilgisi alan bilgisi sosyal yönleri ve kişiliklerine ilişkin bir araştırma. Eğitim Araştırmaları Dergisi (Eurasian Journal of Educational Research), 5(17), 169-179.

Gözütok, D., Akgün, Ö. E., ve Karacaoğlu, Ö. C. (2005). Yeni ilköğretim programlarının uygulanmasına öğretmenlerin hazırlanması. Ĕgitimde Yansımalar: VIII Yeni İlköğretim Programlarını Değerlendirme Sempozyumu Bildiriler, 14-16 Kasim 2005, Kayseri, ss.17-41.

Gürol, M. (2002). Aktif öğrenmeyi temel alan oluşturmacı öğrenme tasarımının uygulanması ve başarıya etkisi. NTIE Bildiriler Kitabı (ss.82-95), İzmir. $\quad$ Erişim: $\quad 11.08 . \quad 2007$ http://manas.kg/pdf/sbdpdf7/Gurol.pdf

Hassard, J. (1999). Students' Experience in Constructivist Learning Environments: An Inquiry into TEEMS... a Science Teacher Education Program. Paper Presented at the $6^{\text {th }}$ Nordic Research Conference on Science Education, Joensuu, Finland. [Online]: Retrieved on 11.02.2007, at http://www.gsu.edu/ mstjrh/teemsfinland.html.

Herne, S. (2000). Study to Teach: A Guide to Studying in Teacher Education. Herne, S., Jessel, J. \& Griffiths, J. (2000) Study to teach, a guide to studying in teacher education, London: Routedge.

Hewett, S. M. (2003). Learner-centered teacher preparation a mastery of skills. Education, 124 (1), 24-30. 
Kalaycı, Ş. (2005). Faktör analizi. Ş. Kalaycı (Editör). SPSS uygulamalı çok değişkenli istatistik teknikleri (ss. 321-331). Ankara: Asil Yayın Dağıtım Ltd. Şti.

Karasar, N. (1991). Bilimsel araştırma yöntemi. (4. Basım) Ankara: 3A Araştırma Eğitim Danışmanlık Ltd. Şti.

Kesal, F. (2003). Ingilizce öğretmenliği özel öğretim yöntemleri II derslerindeki oluşturmacl sinıf özelliklerinin araştırılması. Yayınlanmamış doktora tezi. Ortadoğu Teknik Üniversitesi, Sosyal Bilimler Enstitüsü, Ankara.

Kesal, F. ve Aksu, M. (2006). ELT Studens' Perception of Constructivist Learning Activities and Evaluation Strategies. Eğitim Araştırmalar Dergisi, 24, 134-142.

Kılıç, D., Nalçacı, A. ve Ercoşkun, H. (2004). İlköğretimde Değişen Planlar ve Karşılaşılan Problemler. XIII. Ulusal Eğitim Bilimleri Kurultayı. 6-9 Temmuz 2004. Malatya: İnönü Üniversitesi Eğitim Fakültesi.

Kinnucan-Welsch, K. \& Jenlink, P. M. (1998). Challenging assumptions about teaching and learning: three case studies in constructivist pedagogy. Teaching and Teacher Education, 14(4), 413-427.

Koç, G., ve Demirel, M. (2004). Davranışçılıktan yapılandırmacılığa: Eğitimde yeni bir paradigma. Hacettepe Üniversitesi Ĕ̈itim Fakültesi Dergisi, 27(3), 174-180.

Kroll, L. R. (2004). Constructing constructivism: How student-teachers construct 1deas of development, knowledge, learning, and teaching. Teacher and Teaching: Theory and Practice, 10(2), 199-221.

MEB (Milli Eğitim Bakanlı̆̆ı) http://programlar.meb.gov.tr/prog_giris/prog_giris_1.html [Online]: adresinden 01. 09. 2005 tarihinde ulaş1ld.

Niemi, H. (2002). Active learning- a cultural change needed in teacher education and schools. Teaching and Teacher Education, 18(7), 763780.

Oldfather, P.; Bonds, S. \& Bray, T. (1994). Stalking the fuzzy sunshine seeds: Constructivist processes for teaching about constructivism in teacher education. Teacher Education Quarterly, 21(3), 5-14.

Olsen, D. G. (1999). Constructivist principles of learning and teaching methods. Education, 120(2), 347-355.

Özden, Y. (2003). Öğrenme ve ögretme. Ankara: Pegem A Yayınc1lık.

Pankratius, W. J. \& Young, M. W. (1995). Perspectives on education: A constructivist approach to an introductory course. Education, 115(3), 363-370.

Pierce, J. W. \& Kalkman, D. L. (2003). Applying learner centered principles in teacher education. Theory Into Practice, 42(2), 127-132. 
Plourde, L. A. \&, Alawiye, O. (2003). Constuctivism and elementary preservice science teacher preparation: Knowledge to application. College Student Journal, 37 (3), 334-341.

Rainer, J. \& Guyton, E. (1999). Democratic practices in teacher education and the elementary classroom. Teaching and Teacher Education, 15 (1), 121-132.

Richardson, V. (2003). Constructivist pedagogy. Teachers College Record, 105(9), 1623-1640.

Saban, A. (2000). Öğrenme öğretme süreci yeni teori ve yaklaşımlar. Ankara: Nobel Yayınları.

Senemoğlu, N. (1994). Sınıf öğretmeni bilgiyi aktaran kişi değil, bilgiye ulaşma yollarını öğreten kişidir. MPM Kalkınmada Anahtar Verimlilik, 81. [Online]: 19.01.2007 tarihinde ulaş1ld,

http://www.epo.hacettepe.edu.tr/eleman/nuray_hoca/makaleler/sinif_ogr.htm 1.

So, W. \& Watkins, D. A. (2005). From beginning teacher education to professional teaching: A study of the thinking of hong kong primary science teachers. Teaching and Teacher Education. 21, 525-541.

Sönmez, V. (2004). Program geliştirmede ögretmen elkitabı. (11.Bask1). Ankara: Anı Yayınc1lık.

White, C. (1995). The place for technology in a constructivist teacher education program. Technology and Teacher Education Annual 1995 (pp.290-293). Charlottesville, VA: Association for the Advancement of Computing in Education.

Yager, R. E. (1991). The constructivist learning model towards real reform in science education. The Science Teacher. National Science Teachers Association, 58(6), 52-57.

Yanpar Şahin, T. (2003). Student teachers' perceptions of instructional technology: Developing materials based on a constructivisit approach. British Journal of Educational Technology, 34(1), 67-74.

Yıldırım, A. (2003). Instructional planning in a centralized school system: Lessons of a study among primary school teachers in Turkey. International Review of Education. 49(5), 525-543.

YÖK (1998). Eğitim Fakültesi Öğretmen Yetiştirme Lisans Programlart. Ankara.

http://www.yok.gov.tr/egitim/ogretmen/ogretmen_yetistirme_lisans/rap or.pdf adresinden 01. 09. 2005 tarihinde ulaş1ld.

YÖK/Dünya Bankası (1998). Fakülte-okul işbirliği kalavuzu. Ankara: YÖK/Dünya Bankası Milli Eğitimi Geliştirme Projesi Hizmet Öncesi Öğretmen Eğitimi, Öğretmen Eğitimi Dizisi.

Yurdakul, B. (2005). Yapılandırmacılık. Ö. Demirel (Ed.), Eğitimde Yeni Yönelimler (pp. 39-65). Ankara: Pegem A Yayınc1lı. 
